\title{
PERAN DAN FUNGSI KOMUNIKASI MASSA
}

\author{
Oleh: Qudratullah \\ Dosen Pada Jurusan Jurnalistik \\ Fakultas Dakwah dan Komunikasi \\ STAIN Parepare
}

\begin{abstract}
:
This research concentrates with the function and the role of mass communication which has a significant contribution toward people's life. The objective of this research is to figure out the role and the function of mass communcation. The use of method is qualitative and the technique analysis is about descriptive analysis. The data collected by exploring all literatures related to mass communication. The result of this clarifies that the role and the function of mass communciation are still sticking with their function and role that are live experiencing, communicator, information taker, interactive network, and road mapping. The function is qualified by providing information, education, influencing, and entertainment.
\end{abstract}

Key words:

Mass Communication, Function, Role.

\section{PENDAHULUAN}

Perkembangan teknologi informasi dan komunikasi saat ini sangat pesat. Hal ini memberikan peluang besar terjadinya praktik komunikasi yang lebih efektif dibandingkan dengan masa lalu. Semua itu terjadi karena ditunjang dengan kemajuan teknologi. Kini, teknologi sangat dibutuhkan dalam rangka memenuhi tuntutan zaman karena dengan adanya teknologi, manusia mampu menyebarkan dan menerima pesan tanpa mengenal batasan tempat dan waktu.

Untuk lebih mempermudah pengiriman dan penerimaan pesan dalam proses komunikasi tentunya dibutuhkan media sebagai saluran penghubung antara komunikan dan komunikator. Dalam dunia jurnalistik, media menjadi sumber informasi yang sangat dibutuhkan oleh masyarakat banyak. Kebutuhan akan suatu informasi atau berita juga membuat media berkembang pesat seiring dengan perkembangan teknologi.

Seiring perkembangan teknologi informasi dan komunikasi, masyarakat tidak lagi dibatasi dalam berkomunikasi oleh jumlah, bahkan dalam komunikasi massa masyarakat bahkan tak terbatas dalam melakukan komunikasi.

Komunikasi massa merupakan komunikasi yang memiliki unsur seperti komunikasi pada umumnya, namun membutuhkan gatekeeper dalam proses komunikasi tersebut. ${ }^{1}$

Dari jangkuan komunikasi yang luas, komunikasi massa tentu memiliki peran dan fungsi-fungsi yang beragam. Untuk memahami fungsi yang ada dalam komunikasi massa, penulis membahas peran dan fungsi dalam komunikasi massa. 


\section{PEMBAHASAN}

\section{Peran Komunikasi Massa}

Komunikasi massa berperan penting dalam fenomena popularitas individu, organisasi atau lembaga tertentu. Nama-nama populer di masyarakat seperti dari kalangan politik, ekonomi, intelektual sosial, hiburan, olah raga dan sebagainya tidak terlepas dari peran pemberitaan media massa.

Media massa menampilkan kepandaian, bakat dan prestasi-prestasi tertentu dari individu sehingga memperoleh perhatian dan apresiasi dari khalayak. Mereka dikenal luas di kalangan masyarakat karena bantuan media. Para pekerja seni (entertainer) lahir dari peran serta media massa dalam meliput dan menampilkannya. Demikian pula dengan profesi atau ajang yang menunjukkan talenta lainnya. ${ }^{2}$

Keberadaan media semakin memberikan dampak yang sangat besar bagi khalayak. Bukan hanya melalui televisi, sosial media seperti Instagram dan You Tube saat ini juga menjadi lahan orang-orang yang ingin menarik perhatian khalayak. Yang sebelumnya merangkak untuk terkenal, akan menjadi fenomenal setelah adanya sentuhan media massa.

Menurut Dommick dalam Elvinaro Ardianti dkk, fenomena terbentuknya selebritas di bidang keartisan atau pakar di bidang politik, ekonomi, komunikasi dan lainnya tidak terlepas dari peran yang dimainkan komunikasi massa dalam kehidupan masyarakat. Begitupun dalam bidang produk kebutuhan hidup. Khalayak saat ini dipermudah dalam mengetahui di mana supermarket yang menyediakan barang yang diperlukan karena adanya iklan pada media massa. Melalui komunikasi massa, khalayak semakin banyak memperoleh informasi yang berdampak pada keberagaman informasi khalayak. ${ }^{3}$

Para pengusaha tidak sungkan-sungkan mengeluarkan dana yang fantastis dalam mempromosikan produk yang dijualnya melalui media massa karena menganggap sebagai media massa paling efektif dalam memperkenalkan produk kepada masyarakat luas.

Saat ini bukan hanya melalui televisi, radio ataupun media cetak, tetapi promosi produk juga seringkali dilakukan di media sosial utamanya Instagram. Produk para pengusaha di-endorse oleh orang-orang yang dianggap memiliki kapasitas dan kredibilitas dalam memperkenalkan produknya melalui media sosial.

Tak hanya pengusaha, politisi juga seperti itu. Mereka mengeluarkan banyak dana untuk memperkenalkan diri dan partainya melalui iklan-iklan di media cetak ataupun mempromosikan diri secara pribadi melalui postingan di beberapa media sosial.

McQuail dalam Halik, mendefenisikan peran media massa sebagai berikut:

1. Jendela pengalaman yang meluaskan pandangan dan memungkinkan kita mampu memahami apa yang terjadi di sekitar kita, tanpa campur tangan pihak lain atau sikap memihak.

2. "Juru bahas" yang menjelaskan dan memberi makna terhadap peristiwa atau hal yang terpisah dan kurang jelas.

3. "Pembawa atau penghantar" informasi dan pendapat. 
4. “Jaringan interaktif" yang menghubungkan pengirim dengan penerima melalui berbagai macam umpan balik.

5. "Petunjuk jalan" yang secara aktif menunjukkan arah, memberikan bimbingan atau instruksi.

6. Penyaring yang memilih bagian pengalaman yang perlu diberi perhatian khusus dan menyisihkan aspek pengalaman lainnya baik secara sadar dan sistematis atau tidak.

7. "Cermin" yang memantulkan citra masyarakat terhadap masyarakat itu sendiri. Biasanya pantulan citra itu mengalami perubahan (distorsi) karena adanya penonjolan terhadap segi yang ingin dilihat anggota masyarakat, atau sering segi yang ingin mereka hakimi atau cela.

8. "Tirai" atau penutup yang menutupi kebenaran demi pencapaian tujuan propaganda atau pelarian dari suatu kenyataan (escapism). ${ }^{4}$

Dengan demikian, secara umum peranan media massa data dilihat pada dua sisi yang berbeda. Media massa dapat berperan positif dalam b erbagai aspek kehidupan manusia, tetapi jugadapat berperan negatif dalam kehidupan manusia. Media menjalankan peranan dalam kehidupan sosial dengan melakukan hal-hal berikut:

a. Penyebar informasi yang objektif dan edukatif

b. Melakukan kontrol sosial yang konstruktif

c. Menyalurkan aspirasi rakyat dan memperluas komunikasi dan partisipasi masyarakat. ${ }^{5}$

\section{Fungsi Komunikasi Massa}

Para pakar mengemukakan tentang sejumlah fungsi komunikasi yang memiliki persamaan dan perbedaan. Pembahasan terkait fungsi komuniasi massa menjadi hal yang penting untuk diidiskusikan.

Beberapa pakar yang mengemukakan fungsi komunikasi massa adalah Domminick yang terdiri dari surveillance (pengawasan), interpretations (penafsiran), linkage (keterkaitan), transmissions of values (penyebaran nilai, dan entertainment (hiburan). ${ }^{6}$

Kemudian Effendy juga memberikan fungsi komunikasi massa yakni sebagai informasi, pendidikan, dan memengaruhi. ${ }^{7}$ Selanjutnya DeVito menyebutkan fungsi komunikasi massa secara khusus adalah meyakinkan (to persuade), menganugerahkan status, membius (narcotization), kenciptakan rasa kesatuan, privatiasi dan hubungan parasosial. ${ }^{8}$

McQuail sendiri membedakan fungs komunikasi massa bagi masyarakat dan fungsi komunikasi massa bagi individu. Fungsi komunikasi massa untuk individu yakni infomasi, korelasi, kesinambungan, hiburan dan mobilisasi. Sedangkan fungsi komunikasi untuk individu yakni informasi, identitas pribadi, integrasi dan interaksi sosial.

Dari beberapa fungsi komunikasi yang dikemukakan oleh para pakar di atas penulis menyimpulkan beberapa fungsi komunikasi adalah: 


\section{Informasi}

Fungsi informasi merupakan fungsi paling penting yang terdapat dalam komunikasi massa. Kompenen paling urama untuk mengetahui fungsi informasi ini adalah berita-berita yang disajikan. Iklan oun beberapa hal yang memiliki fungsi memberikan informasi disamping fungsi-fungsi lain. ${ }^{9}$

Dari aspek ini, komunikasi massa menyediakan informasi tentang peristiwa dan kondisi dalam mesyarakat dan dunia, menunjukkan hubungan kekuasaan, dan memudahkan inovasi, adaptasi dan kemajuan. ${ }^{10}$

Fungsi informasi dapat diartikan bahwa media massa adalah penyebar informasi bagi khalayak. Berbagai informasi dibutuhkan oleh khalayak media massa yang berkaitan sesuai dengan kebutuhan dan kepentingannya. Sebagai makhluk sosial, khalayak akan terus membutuhkan informasi.

Saat ini selain berlangganan koran dan menonton TV dan mendengarkan radio, khalayak juga telah dipermudah dengan keberadaan media online dan media sosial yang semakin membantu masyarakat dalam memperoleh informasi secara up to date dan real time.

Oleh karea itu, sudah sapat dikatakan bahwa fungsi informasi menjadi hal yang sangat penting bagi masyarakat seiring dengan perkembangan teknologi informasi dan komunikasi.

2. Fungsi pendidikan

Media massa merupakan sarana pendidikan bagi khalayak (mass education), karena banyak menyajikan hal-hal yang sifatnya mendidik. Salah satu cara mendidik yang dilakukan media massa adalah melalui pengajaran nilai, etika serta aturan-aturan yang berlaku kepada pemirsa atau pembaca. Media massa melakukannya melalui drama, cerita, diskusi, dan artikel. $^{11}$

3. Fungsi Memengaruhi

Fungsi memengaruhi dari media massa terdapat pada tajuk atau editorial, features, iklan artikel, dan sebagainya. Khalayak dapat terpengaruh oleh iklan-iklan yang ditayangkan televisi maupun surat kabar. ${ }^{12}$

Menurut DeVito, fungsi memengaruhi dianggap sebagai fungsi yang oaling penting dari komunikasi massa. Memengaruhi bisa datang dari berbagai macam bentuk yaitu:

a. Mengukuhkan atau memperkuat sikap, kepercayaan atau nilai seseorang

b. Mengubah sikap, kepercayaan atau nilai seseorang

c. Menggerakkan seseorang untuk melakukan sesuatu

d. Memperkenalkan etika atau menawarkan sistem nilai tertentu. ${ }^{13}$

\section{Fungsi Hiburan}

Fungsi hiburan ppada media elektronik menduduki posisi yang paling tinggi dibandingkan dengan fungsi-fungsi yang lain karena masyarakat kebanyakan menggunakan menggunakan televisi sebagai media hiburan. Sedangkan media cetak biasanya tidak menempatkan hiburan pada posisi teratas tetapi informasi. Namun, media cetak juga hraus member fungsi hiburan. ${ }^{14}$ Gambar-gambar berwarna yang kerap muncul pada beberapa rubric 
atau pada rubric khusus menjadi bukti bahwa media cetak juga memberikan hiburan kepada pembaca.

Tujuan fungsi hiburan adalah menyediakan hiburan, pengalihan perhatian, dan sarana relaksasi serta meredakan ketegangan sosial bagi masyarakat. Sedangkan bagi individu berfungsi melepaskan diri diri atau terpisah dari permasalahan, bersantai, memperoleh kenikmatan jiwa dan estetis, dan mengisi waktu, penyaluran emosi. ${ }^{15}$

\section{SIMPULAN}

1. Peran media massa sebagai berikut:

a. Jendela pengalaman yang meluaskan pandangan dan memungkinkan kita mampu memahami apa yang terjadi di sekitar kita, tanpa campur tangan pihak lain atau sikap memihak.

b. "Juru bahas" yang menjelaskan dan memberi makna terhadap peristiwa atau hal yang terpisah dan kurang jelas.

c. "Pembawa atau penghantar" informasi dan pendapat.

d. “Jaringan interaktif' yang menghubungkan pengirim dengan penerima melalui berbagai macam umpan balik.

e. "Petunjuk jalan" yang secara aktif menunjukkan arah, memberikan bimbingan atau instruksi.

f. Penyaring yang memilih bagian pengalaman yang perlu diberi perhatian khusus dan menyisihkan aspek pengalaman lainnya baik secara sadar dan sistematis atau tidak.

g. "Cermin" yang memantulkan citra masyarakat terhadap masyarakat itu sendiri. Biasanya pantulan citra itu mengalami perubahan (distorsi) karena adanya penonjolan terhadap segi yang ingin dilihat anggota masyarakat, atau sering segi yang ingin mereka hakimi atau cela.

h. "Tirai" atau penutup yang menutupi kebenaran demi pencapaian tujuan propaganda atau pelarian dari suatu kenyataan (escapism).

2. Fungsi Komunikasi Massa:
a. Fungsi Informasi
b. Fungsi Pendidikan
c. Fungsi Memengaruhi
d. Fungsi Hiburan. 


\section{Endnote}

${ }^{1}$ McQuail, Teori Komunikasi Massa (Terj. Agus Dharma dan Amiruddin; Jakarta: Erlangga, 1997),h. 56.

${ }^{2}$ Abdul Halik, Komunikasi Massa (Makassar: Alauddin University Press, 2013), h. 65.

3 Dominick dalam Elvinaro Ardianto dkk, Komunikasi Massar Suatu Pengantar (Bandung: Refika Offset, 2009), h. 12.

${ }^{4}$ McQuail dalam Abdul Halik, Komunikasi Massa (Makassar: Alauddin University Press, 2013), h. 6566.

\footnotetext{
${ }^{5}$ Abdul Halik, Komunikasi Massa (Makassar: Alauddin University Press, 2013), h. 66.

${ }^{6}$ Elvinaro Ardianto dkk, Komunikasi Massa Suatu Pengantar, h. 14-17.

${ }^{7}$ Elvinaro Ardianto dkk, Komunikasi Massa Suatu Pengantar, h. 18-19.

${ }^{8}$ Elvinaro Ardianto dkk, Komunikasi Massa Suatu Pengantar, h. 20-23.

${ }^{9}$ Nurudin, Pengantar Komunikasi Massa (Jakarta: Raja Grafindo Persada, 2007), h. 66.

${ }^{10}$ Abdul Halik, Komunikasi Massa (Alauddin University Press, 2013), h. 57.

${ }^{11}$ Elvinaro Ardianto dkk, Komunikasi Massa Suatu Pengantar, h. 18.

${ }^{12}$ Elvinaro Ardianto dkk, Komunikasi Massa Suatu Pengantar, h. 18.

${ }^{13}$ Nurudin, Pengantar Komunikasi Massa, h. 72-73.

${ }^{14}$ Nurudin, Pengantar Komunikasi Massa, h. 70-71.

${ }^{15}$ Abdul Halik, Komunikasi Massa, 58-59.
}

\section{DAFTAR PUSTAKA}

Ardianto, Elvinaro. Komunikasi Massa Suatu Pengantar. Bandung: Refika Offset. 2009.

Halik, Abdul. Komunikasi Massa. Makassar: Alauddin University Press. 2013.

McQuail. Teori Komunikasi Massa. Jakarta: Erlangga. 1997.

Nurudin. Pengantar Komunikasi Massa. 